\title{
Asynchronous dan Engaged Learning Terhadap Minat Anak-Anak Mengikuti Sekolah Minggu
}

\author{
The Use of Asynchronous and Engaged Learning to Generate
}

Children's Interest in Sunday School

\begin{abstract}
Author:
- Lidia Susanti

- Kiki Pawestri

Ayuningtyas ${ }^{2}$

\section{Affiliation:}

${ }^{1}$ STIPAK Malang

lidiasusanti@stipakdh.ac.id

${ }^{2}$ STIPAK Malang

Dates:

Submitted:

13 September 2021

Accepted:

24 October 2021

Published:

12 November 2021

DOI:
\end{abstract}

10.46494/psc.v17i2.157

\section{Copyright:}

(C) 2021. The Authors. Licensee: This work is licensed under the Creative Commons Attribution-ShareAlike 4.0 International License.

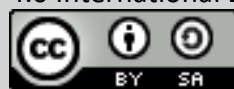

Abstract: During the pandemic, Sunday School activities have challenges: Sunday school teachers are not familiar with technology, children are not used to technology and online meetings. This research was conducted by simple random sampling in several churches in East Java in the Middle class. The total population is 60 children, and the sample taken is 52 children. Data analysis measures the relationship between variables using a correlation test and the magnitude of the influence between variables. This study shows that a teacher can start the Sunday school activities with asynchronous learning during the pandemic using YouTube and WhatsApp media combined with engaged learning strategies that can make children feel involved.

[Kegiatan Sekolah Minggu selama masa pandemi memiliki tantangan antara lain: guru sekolah minggu belum terbiasa dengan teknologi, anak-anak tidak terbiasa dengan teknologi dan pertemuan online. Penelitian ini dilakukan secara simple random sampling pada beberapa gereja di Jawa Timur pada kelas Madya. Jumlah populasi ada 60 anak dan sample yang diambil 52 anak. Analisis data mengukur adanya hubungan antar variabel menggunakan uji korelasi dan besarnya pengaruh antar variabel. Penelitian ini menunjukkan bahwa pada masa pandemi, kegiatan sekolah minggu dapat diawali dengan asynchronous learning menggunakan media YouTube dan whatsapp dengan dikombinasi penggunaan strategi engaged learning yang dapat membuat anak-anak merasa terlibat.]

Research Contribution: Riset ini mengembangkan metode asynchronous learning sebagai strategi pembelajaran kontekstual di Sekolah Minggu dalam disiplin ilmu praktika gereja.

Keywords: asynchronous learning, Sunday school, christian education, teacher, pandemic

\section{Pendahuluan}

-jak adanya pandemi yaitu virus mematikan Corona Virus Disease 2019 (Covid-19), maka terjadi perubahan yang berdampak sangat signifikan pada berbagai bidang khususnya di Indonesia pada awal Maret 2020. Tidak terelakkan, dampaknya juga terjadi pada gerejagereja, baik dalam pelaksanaan ibadah umum maupun kegiatan Sekolah Minggu, dimana semua kegiatan onsite harus terhenti 
dan ditutup. ${ }^{1}$ SK Menteri Mendikbud Nadiem

A. Makarim

bernomor

36962/MPK.A/HK/2020

tentang

Pembelajaran secara Daring dan Bekerja dari Rumah dalam Rangka Pencegahan Penyebaran Covid-19, menyebakan kegiatan ibadah perlu dilakukan di rumah, termasuk kegiatan Sekolah Minggu. ${ }^{2}$ Adanya himbauan bahwa semua kegiatan harus dari rumah, maka hal ini direspon positif oleh gereja sehingga semua kegiatan ibadah diadakan secara online, termasuk kegiatan Sekolah Minggu dilakukan secara online.

Penelitian tentang Sekolah Minggu dilakukan pada sebuah denominasi, awal pandemi Covid19 ditemukan bahwa hanya tiga gereja saja yang melakukan kegiatan sekolah minggu online, sedangkan gereja-gereja lainnya di Indonesia tidak mengadakan ibadah sekolah minggu baik itu online maupun tatap muka. Salah satu alasan yang diungkapkan adalah karena kurang paham teknologi ataupun karena berasal dari keluarga ekonomi menengah kebawah. Berdasarkan hasil temuan tersebut, dapat diketahui bahwa ternyata pada masa pandemi Covid-19, banyak gereja yang tidak mengadakan ibadah sekolah minggu sehingga banyak anak-anak tidak dapat mengikuti kegiatan sekolah minggu. 3

Adanya kendala teknologi di awal pandemi, maka banyak orang mulai belajar

\footnotetext{
${ }^{1}$ Michael Teng and Carmia Margaret, "Sketsa Pelayanan Gereja Sebelum, Selama, Dan Sesudah Masa Pandemi COVID-19," Veritas: Jurnal Teologi Dan Pelayanan, 2020, https://doi.org/10.36421/veritas.v19i2.432.

2 Yusup Rogo Yuono, "Pertumbuhan Gereja Di Masa Pandemi," Sagacity 65, no. 2 (2020).

3 Karnawati Karnawati and Mardiharto Mardiharto, "Sekolah Minggu Masa Pandemi Covid 19: Kendala, Solusi, Proyeksi," Didache: Journal of Christian Education 1, no. 1 (2020): 13,

https://doi.org/10.46445/djce.vii1.291.

4 Ria Yunitasari and Umi Hanifah, "Pengaruh Pembelajaran Daring Terhadap Minat Belajar Siswa Pada Masa COVID 19," EDUKATIF : JURNAL ILMU PENDIDIKAN 2, no. 3 (2020),

https://doi.org/10.31004/edukatif.v2i3.142.

5 Ellen Chung, Geetha Subramaniam, and Laura Christ Dass, "Online Learning Readiness among University
}

menggunakan teknologi untuk menyampaikan pembelajaran secara online, ada beberapa template 4 yang dapat digunakan pada pembelajaran online antara lain: zoom, google classroom, google meet, whatsaap, facebook, Instagram, Youtube.5 Melalui template ini dibedakan pembelajaran secara asynchronous dan synchronous. Pembelajran asynchronous adalah pembelajaran yang menggunakan internet sehingga dapat melakukan komunikasi antara pendidik dan peserta didik, di mana pembelajaran ini dapat dilakukan dimana saja dalam memberikan informasi dan dapat ditransmisikan materi secara internet. ${ }^{6}$

Beberapa kelebihan pembelajaran online asynchronous antara lain: akan memberikan dampak yang positif pada siswa 7 sehingga dapat mempengaruhi minat belajar siswa. Pembelajaran online dapat di desain dengan berpusat pada siswa ${ }^{8}$ sehingga dapat melibatkan keaktifan siswa. Selain itu pembelajaran asynchronous membuat peserta didik dapat belajar materi lebih dalam untuk memperluas pengetahuan mereka9, mengembangkan kebebasan berpendapat sehingga dapat meningkatkan pengetahuan

Students in Malaysia amidst Covid-19," Asian Journal of University Education 16, no. 2 (2020): 45-58, https://doi.org/10.24191/AJUE.V16I2.10294.

${ }^{6}$ Gavin Northey et al., "Increasing Student Engagement Using Asynchronous Learning," Journal of Marketing Education 37, no. 3 (2015), https://doi.org/10.1177/0273475315589814.

7 Northey et al.

8 Khadijah Mukhtar et al., "Advantages, Limitations and Recommendations for Online Learning during Covid-19 Pandemic Era," Pakistan Journal of Medical Sciences 36, no. COVID19-S4 (2020), https://doi.org/10.12669/pjms.36.COVID19-S4.2785. 9 Xiaoyu Zhang et al., "DeepPAR and DeepDPA: Privacy Preserving and Asynchronous Deep Learning for Industrial IoT," IEEE Transactions on Industrial Informatics 16, no. 3 (2020), https://doi.org/10.1109/TII.2019.2941244. 
mereka ${ }^{10}$, dapat belajar melalui video pendek ${ }^{11}$ untuk melatih memecahkan masalah dan memperdalam pemahaman peserta didik. Kepuasan peserta didik pada pembelajaran asynchronous dipengaruhi oleh budaya, media digital, teknologi pribadi dan seluler, preferensi pembelajaran peserta didik, pedagogi, kompleksitas, dan generasi digital. ${ }^{12}$

\section{Sedangkan kekurangan pembelajaran} asynchronous adalah dalam melakukan evaluasi hasil belajar online, terkadang berdampak negative pada nilai ujian ${ }^{13}$, dan komunikasi melalui asynchronous tidak terjadi di waktu yang sama. Selain itu menggunakan asynchronous learning memiliki respon yang lebih lama. Bahkan dalam media asynchronous learning anak-anak terputus dari bimbingan guru secara langsung dan terputus dari komunitas kelas sehingga diibutuhkan motivasi internal yang tinggi dan kecakapan belajar mandiri yang berkembang. ${ }^{14}$

Pembelajaran online perlu memperhatikan beberapa hal, salah satunya adalah strategi pembelajaran. Penggunaan strategi pembelajaran yang tepat akan mempengaruhi transfer pedagogi yang tepat pula. ${ }^{15}$ Pembelajaran online dengan asynchronous

${ }^{10}$ Muhammad Javed, Akhtar Ali, and Azhar Mahmood, "Impact of Globalization on Postgraduate Students' Asynchronous Learning in English Language," Pakistan Journal of Distance and Online Learning 4, no. 2 (2018): 67-86.

${ }^{11}$ Adam M. Garber, "Flipping Out! Utilizing an Online Micro-Lecture for Asynchronous Learning Within the Acting Internship," Medical Science Educator 30, no. 1 (2020), https://doi.org/10.1007/s40670-019-00887-y. 12 Charles Dziuban et al., "STUDENT SATISFACTION WITH ASYNCHRONOUS LEARNING," Online Learning 11, no. 1 (2019),

https://doi.org/10.24059/olj.v11i1.1739.

13 Edward K. Lew and Erik K. Nordquist, "Asynchronous Learning: Student Utilization out of Sync with Their Preference," Medical Education Online 21, no. 1 (2016), https://doi.org/10.3402/meo.v21.30587.

14 Cynthia Mary Sistek-Chandler Ed., Exploring Online Learning through Synchronous and Asynchronous Instructional Methods. Advances in Mobile and Distance Learning (AMDL) Book Series, IGI Global, 2020, https://doi.org/http://dx.doi.org/10.4018/978-17998-1622-5. learning juga membutuhkan strategi pembelajaran yang tepat agar dapat melibatkan peserta didik dalam pembelajaran (engaged learning), sehingga mendorong keaktifan peserta didik selama proses pembelajaran berlangsung. ${ }^{16}$

Strategi pembelajaran online dengan asynchronous learning yang telah diteliti, antara lain menggunakan metode diskusi online dengan chating dan engaged learning, dimana perpaduan pembelajaran ini dapat melibatkan keaktifan peserta didik sehingga dapat meningkatkan hasil belajar peserta didik ${ }^{17}$, juga dapat menggunakan video kuliah online yang dapat meningkatkan keterlibatan dan kepuasan peserta didik, sambil mempertahankan hasil belajar yang tinggi dalam pendidikan online. ${ }^{18}$

Beberapa penelitian di atas dapat memberi acuan tentang kelebihan penggunaan asynchronous learning dan enganged learning dalam pembelajaran formal, maka pada penelitian ini akan dilakukan survey penelitian pada anak-anak Sekolah Minggu, yang selama masa pandemi ini menggunakan media asynchronous. Tujuan penelitian ini untuk mengetahui minat anak-anak dalam mengikuti
15 Pilar Gómez-Rey, Elena Barbera, and Francisco Fernández-Navarro, "Student Voices on the Roles of Instructors in Asynchronous Learning Environments in the 21st Century," International Review of Research in Open and Distance Learning 18, no. 2 (2017), https://doi.org/10.19173/irrodl.v18i2.2891.

${ }^{16}$ Eirini Geraniou and Cosette Crisan, "University Students' Engagement with an Asynchronous Online Course on Digital Technologies for Mathematical Learning," Eleventh Congress of the European Society for Research in Mathematics Education, no. 2002 (2019).

17 Tracy Douglas et al., "Online Discussion Boards: Improving Practice and Student Engagement by Harnessing Facilitator Perceptions," Journal of University Teaching and Learning Practice 17, no. 3 (2020), https://doi.org/10.53761/1.17.3.7.

18 Ronny C. Choe et al., "Student Satisfaction and Learning Outcomes in Asynchronous Online Lecture Videos," CBE Life Sciences Education 18, no. 4 (2019), https://doi.org/10.1187/cbe.18-08-0171. 
Sekolah Minggu walau tidak dapat pergi ke gereja.

\section{Metode}

Penelitian ini merupakan penelitian kuantitatif yang menggunakan metode survey eksplanatori, design cross sectional studies. Design ini bertujuan untuk mengetahui kecenderungan yang terjadi, diwakili oleh sampel yang merepresentasikan populasi dan menekankan pada pencarian hubungan kausalitas antara variable yang diteliti. ${ }^{19}$ Penelitian ini memiliki populasi Sekolah Minggu yang ada di Jawa Timur. Sampel pada penelitian ini adalah anak-anak yang mengikuti kelas madya dengan menggunakan media youtube, antara lain di GSJA "Maranatha" Malang, GSJA "Trinitas" Mergan, GSJA "Haleluya" Mondoroko, GSJA "Shalom" Malang, GSJA "Maranatha Family" Batu, GSJA "Penuaian" Malang, GSJA "Solagratia" Kedawung, GSJA "Umbul Sari” Jember, GSJA "Anugerah" Tegaron, GSJA Jatiguwi, GSJA "Sungai Kehidupan" Surabaya dan Gereja Mawar Sharon Surabaya. Jumlah populasi 60 dan sampel yang digunakan dalam penelitian ini adalah 52 orang (table Slovin $5 \%$ ).

Pada penelitian ini, variabel independent $\left(\mathrm{X}_{1}\right)$ adalah asynchronous learning dan variabel $\mathrm{X}_{2}$ adalah engaged learning. Sedangkan variabel dependent ( $\mathrm{Y}$ ) adalah minat anak-anak mengikuti kegiatan sekolah minggu. Indikator variabel media asynchronous learning $\left(\mathrm{X}_{1}\right)$ adalah video dan obrolan online. Kemudian indikator variabel engaged learning $\left(\mathrm{X}_{2}\right)$ adalah melibatkan anak-anak dalam

\footnotetext{
19 Louis Cohen, Lawrence Manion, and Keith Morrison, Research Methods in Education, Research Methods in Education (New York: Routledge, 2017), https://doi.org/10.4324/9781315456539; Sonny Eli Zaluchu, Sistematika Riset Dan Analisis Data Kuantitatif (Semarang: Golden Gate Publishing, 2018). ${ }^{20}$ Halimatus Saadiah and Abdul Wahid, "Are Students Engaging in Online Classrooms ?," European Journal of Education Studies 7, no. 2019 (2020): 202-22, https://doi.org/10.46827/ejes.v7i12.3408.
}

pembelajaran, sedangkan indikator variabel minat (Y) antara lain: perasaan senang, perhatian anak, ketertarikan anak dalam pembelajaran, dan perasaan terlibat dalam pembelajaran.

Pengumpulan data melalui angket tertutup yang dibagikan kepada anak-anak kelas madya yang mengikuti sekolah minggu dengan menggunakan Youtube atau Whatsapp. Pada penelitian ini, angket yang digunakan adalah angket yang telah diuji sebelumnya yaitu angket asynchronous learning ${ }^{20}$, angket engagement learning ${ }^{21}$, dan angket minat. ${ }^{22}$

Analisis data penelitian dengan uji korelasi tujuannya untuk melihat kuat atau besarnya hubungan antar variabel, kemudian dilakukan uji regresi untuk melihat berapa besar pengaruh variabel asynchronous learning dan engaged learning terhadap minat anak-anak sekolah minggu.

Awalnya, untuk membuktikan keabsahan dari setiap butir pertanyaan, maka dilakukan analisa validitas butir. Analisa validitas butir terhadap variabel media asynchronous learning, engagement learning dan minat anak-anak dalam penelitian ini akan menggunakan teknik korelasi product moment dengan bantuan SPSS 26.o. Indikator kisi-kisi instrumen dari variabel media asynchronous learning, engagement learning dan minat yang ditunjukkan oleh tabel di bawah ini:

Tabel 1: Indikator Pertanyaan

\begin{tabular}{|c|c|c|}
\hline Variabel & Indikator & \multicolumn{1}{c|}{ Pertanyaan } \\
\hline $\begin{array}{c}\text { Pembelajaran } \\
\text { Asynchronous }\end{array}$ & Fitur e-learning & $\begin{array}{l}\text { Sekolah minggu online } \\
\text { dapat membuat saya }\end{array}$ \\
\hline
\end{tabular}

${ }^{21}$ Johnmarshall Reeve and Ching Mei Tseng, "Agency as a Fourth Aspect of Students' Engagement during Learning Activities," Contemporary Educational Psychology 36, no. 4 (2011),

https://doi.org/10.1016/j.cedpsych.2011.05.002.

${ }^{22}$ Siti Hidayatus Sholehah, Diana Endah Handayani, and Singgih Adhi Prasetyo, "MINAT BELAJAR SISWA PADA MATA PELAJARAN MATEMATIKA KELAS IV SD NEGERI KARANGROTO o4 SEMARANG," Mimbar Ilmu 23, no. 3 (2018), https://doi.org/10.23887/mi.v23i3.16494. 


\begin{tabular}{|c|c|c|}
\hline & & $\begin{array}{l}\text { semakin semangat } \\
\text { belajar Firman Tuhan } \\
\text { Saya dengan mudah } \\
\text { mendapatkan link } \\
\text { sekolah minggu online } \\
\text { Sekolah minggu online } \\
\text { lebih menolong saya } \\
\text { belajar Firman Tuhan } \\
\text { baik melalui whatsapp } \\
\text { atau youtube }\end{array}$ \\
\hline & Fitur Video & $\begin{array}{l}\text { Saya lebih mengerti saat } \\
\text { sekolah minggu online } \\
\text { menggunakan video } \\
\text { Saya lebih mudah } \\
\text { mengikuti sekolah } \\
\text { minggu online bila } \\
\text { menggunakan video } \\
\text { Saya lebih mengerti saat } \\
\text { guru bercerita dengan } \\
\text { menggunakan video } \\
\text { Saya lebih suka bila guru } \\
\text { bercerita menggunakan } \\
\text { video }\end{array}$ \\
\hline & $\begin{array}{c}\text { Fitur obrolan } \\
\text { online }\end{array}$ & $\begin{array}{l}\text { Saya lebih mudah } \\
\text { bertanya melalui } \\
\text { whatsapp atau kolom chat } \\
\text { Saya suka mendapatkan } \\
\text { tugas dari sekolah } \\
\text { minggu } \\
\text { Saya suka menggunakan } \\
\text { chatting di youtube dan } \\
\text { whatsapp } \\
\text { Saya senang bisa chatting } \\
\text { di youtube dan whatsapp } \\
\text { sekolah minggu online. }\end{array}$ \\
\hline \multirow[b]{2}{*}{$\begin{array}{c}\text { Engagement } \\
\text { Learning }\end{array}$} & $\begin{array}{c}\text { Keterlibatan } \\
\text { Perilaku }\end{array}$ & $\begin{array}{l}\text { Saya dapat } \\
\text { mendengarkan dengan } \\
\text { baik di kelas sekolah } \\
\text { minggu online } \\
\text { Saya memperhatikan } \\
\text { sekolah minggu online } \\
\text { Saya suka cerita yang } \\
\text { baru di sekolah minggu } \\
\text { Saya berusaha keras } \\
\text { mengerti cerita di } \\
\text { sekolah minggu online } \\
\text { Saya selalu bergabung di } \\
\text { sekolah minggu online. }\end{array}$ \\
\hline & $\begin{array}{c}\text { Keterlibatan } \\
\text { Agen }\end{array}$ & $\begin{array}{l}\text { Selama di kelas sekolah } \\
\text { minggu online, saya } \\
\text { menyampaikan } \\
\text { pendapat saya. } \\
\text { Selama di kelas sekolah } \\
\text { minggu online, saya } \\
\text { mengajukan pertanyaan. } \\
\text { Saya memberi tahu guru } \\
\text { sekolah minggu online } \\
\text { tentang apa yang saya } \\
\text { suka dan apa yang tidak } \\
\text { saya suka. } \\
\text { Saya memberi tahu guru } \\
\text { sekolah minggu online } \\
\text { saya tentang apa yang } \\
\text { saya suka } \\
\text { Saya memberikan ide } \\
\text { tentang sekolah minggu }\end{array}$ \\
\hline
\end{tabular}

\begin{tabular}{|c|c|c|}
\hline & & online \\
\hline & $\begin{array}{c}\text { Keterlibatan } \\
\text { Kognitif }\end{array}$ & $\begin{array}{l}\text { Saya akan mengerjakan } \\
\text { tugas yang diberikan } \\
\text { oleh sekolah minggu } \\
\text { online } \\
\text { Saya melakukan apa } \\
\text { yang disuruh guru } \\
\text { sekolah minggu setiap } \\
\text { hari } \\
\text { Bila saya tidak paham } \\
\text { pelajaran sekolah } \\
\text { minggu online, saya } \\
\text { bertanya kepada } \\
\text { mama/papa/kakak } \\
\text { Saya mencoba mengerti } \\
\text { pelajaran sekolah } \\
\text { minggu online }\end{array}$ \\
\hline & $\begin{array}{c}\text { Keterlibatan } \\
\text { Emosional }\end{array}$ & $\begin{array}{l}\text { Saat saya di kelas } \\
\text { sekolah minggu online, } \\
\text { saya merasa penasaran } \\
\text { dengan apa yang sedang } \\
\text { saya pelajari } \\
\text { Saya tertarik dengan } \\
\text { sekolah minggu online } \\
\text { Saya senang ketika } \\
\text { mempelajari hal-hal baru } \\
\text { di kelas sekolah minggu } \\
\text { online } \\
\text { Kelas sekolah minggu } \\
\text { online menyenangkan }\end{array}$ \\
\hline \multirow{4}{*}{ Minat } & Perasaan & $\begin{array}{l}\text { Saya senang saat sekolah } \\
\text { minggu online } \\
\text { Saya senang dengan } \\
\text { guru sekolah minggu } \\
\text { online } \\
\text { Saya sangat bersemangat } \\
\text { mengikuti sekolah } \\
\text { minggu online }\end{array}$ \\
\hline & Perhatian & $\begin{array}{l}\text { Saya selalu mengingat } \\
\text { pelajaran guru sekolah } \\
\text { minggu online. } \\
\text { Saya mendengarkan } \\
\text { dengan baik setiap cerita } \\
\text { sekolah minggu online } \\
\text { Saya memperhatikan } \\
\text { setiap cerita sekolah } \\
\text { minggu online. }\end{array}$ \\
\hline & Ketertarikan & $\begin{array}{l}\text { Saya bertanya apabila } \\
\text { saya ingin mengetahui } \\
\text { lebih dalam tentang } \\
\text { cerita sekolah minggu. } \\
\text { Saya menghafalkan ayat } \\
\text { hafalan yang diberikan } \\
\text { oleh guru sekolah } \\
\text { minggu } \\
\text { Saya akan mengerjakan } \\
\text { tugas yang diberikan } \\
\text { guru sekolah minggu } \\
\text { online }\end{array}$ \\
\hline & Keterlibatan & $\begin{array}{l}\text { Saya mengingat waktu } \\
\text { sekolah minggu online } \\
\text { Sebelum mengikuti } \\
\text { sekolah minggu saya } \\
\text { mandi terlebih dahulu }\end{array}$ \\
\hline
\end{tabular}




\begin{tabular}{|l|l|}
\hline & Saat guru sekolah \\
& minggu mengajak \\
& berdoa, saya juga ikut \\
& berdoa \\
& Setiap tugas yang akan \\
& diberikan guru sekolah \\
& minggu, akan saya \\
& kerjakan \\
\hline
\end{tabular}

Selanjutnya, setelah dilakukan uji analisa validitas butir pertanyaan, maka dilakukan uji reliabilitas. Uji reliabilitas pertanyaan, setiap variabel dibandingkan dengan nilai Cronbach Alpha, menggunakan nilai minimalnya yaitu o,6 yang tujuannya untuk mengetahui konsistensi pertanyaan yang digunakan. Hasil dari uji reliabilitas yang telah dilakukan pada variabel media asynchronous learning menunjukkan nilai Cronbach Alpha sebesar 0,852 . Sementara itu, hasil uji reliabilitas pada variabel engaged learning memiliki nilai Cronbach Alpha sebesar o,884 dan nilai Cronbach Alpha variabel minat menunjukkan nilai sebesar 0,916 .

Berdasarkan hasil uji reliabilitas pada variabel media asynchronous learning, engagement learning dan minat diketahui bahwa instrumen atau butir pertanyaan yang digunakan pada penelitian adalah reliabel, karena lebih dari 0,6 .

\section{Pembahasan}

\section{Temuan Penelitian}

Variabel media asynchronous learning dalam penelitian ini memiliki skor rata-rata sebesar 46,96. Terdapat 31 anak $(59,62 \%)$ yang menggunakan pembelajaran asynchronous dalam kategori tinggi dan 21 anak (40,38\%) dalam kategori sedang. Secara rinci, hasil penelitian terhadap indikator-indikator pembelajaran asynchronous adalah sebagai berikut:

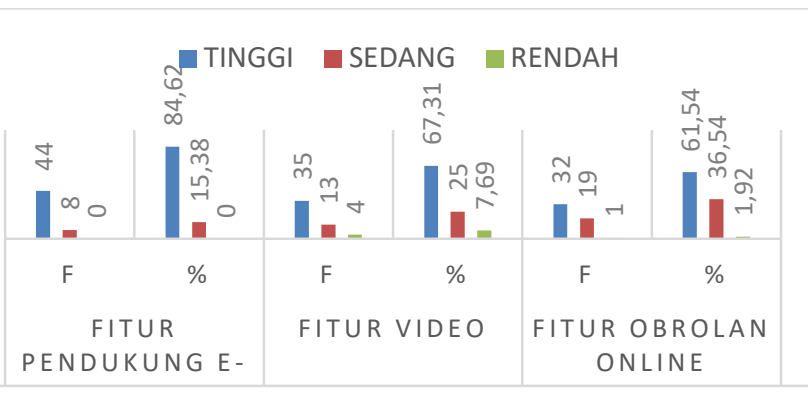

Gambar 1: Indikator Pembelajaran Asynchronous

Penggunaan fitur pendukung e-learning dalam penelitian ini termasuk dalam kategori tinggi memiliki skor rata-rata sebesar 16,67 dan skor ideal 20. Terdapat 44 anak $(84,62 \%)$ yang menggunakan fitur pendukung dalam kategori tinggi, dan terdapat 8 anak yang menggunakan fitur pendukung dalam kategori rendah. Selanjutnya, penggunaan fitur video pendukung e-learning pada kategori sedang, memiliki ratarata sebesar 14,90 dengan skor ideal 20. Terdapat 35 anak $(67,31 \%)$ yang menggunakan fitur video dalam kategori tinggi dan terdapat 13 anak (25\%) dalam kategori sedang. Bahkan, terdapat 4 anak $(7,69 \%)$ yang menggunakan fitur video tergolong dalam kategori rendah. Sedangkan penggunaan obrolan online termasuk kategori tinggi dengan nilai rata-rata 15,38 dengan skor ideal 20. Terdapat 32 anak (61,54\%) yang menggunakan fitur obrolan online dalam kategori tinggi. Terdapat 19 anak (36,54\%) menggunakan fitur obrolan online dalam kategori sedang, dan sisanya 1 anak (1,92\%) menggunakan fitur obrolan online dalam kategori rendah.

Variabel engagement learning dalam penelitian ini memiliki kategori tinggi yaitu dengan nilai rata-rata 69,90, dan masih kurang 20,1 untuk mencapai skor ideal 90, sehingga engagement learning menggunakan asynchronous masih perlu dimodifikasi lagi sehingga mencapai hasil yang maksimal dan hal ini perlu penelitian lebih lanjut. Terdapat 27 anak $(51,92 \%)$ yang terlibat dalam kategori tinggi dan 25 anak (48,08\%) yang terlibat dalam kategori sedang.

Variabel Engagement learning dalam penelitian ini diukur oleh empat indikator, yaitu keterlibatan perilaku, keterlibatan agen, 
keterlibatan kognitif dan keterlibatan emosional. Secara rinci hasil penelitian terhadap indikator-indikator engagement learning adalah sebagai berikut:

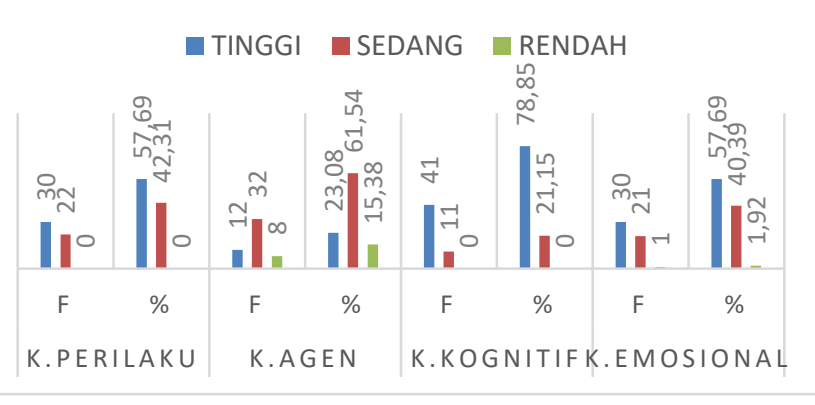

Gambar 2: Indikator Engagement Learning

Keterlibatan perilaku dalam penelitian ini tergolong dalam kategori tinggi yaitu skor ratarata 20,48 dengan skor ideal 25. Terdapat 30 anak $(57,69 \%)$ melakukan keterlibatan perilaku dalam kategori tinggi, dan 22 anak (42,31\%) dalam kategori sedang. Sedangkan keterlibatan agen dalam penelitian ini tergolong kategori sedang yaitu skor rata-rata 16, 62 dengan skor ideal 25. Terdapat 12 anak (23,08\%) melakukan keterlibatan agen dalam kategori tinggi, 32 anak $(61,54 \%)$ tergolong dalam kategori sedang dan 8 anak (15,38\%) tergolong dalam kategori rendah. Kemudian keterlibatan kognitif dalam penelitian ini tergolong dalam kategori tinggi yaitu skor ratarata 16, 92 dengan skor ideal 20. Terdapat 41 anak $(78,85 \%)$ yang melakukan keterlibatan kognitif dalam kategori tinggi dan 11 anak $(21,15 \%)$ dalam kategori sedang.

Terakhir, keterlibatan emosional tergolong dalam kategori tinggi yaitu skor rata-rata 15,88 dengan skor ideal 20. Terdapat 30 anak $(57,69 \%)$ yang melakukan keterlibatan emosional dalam kategori tinggi, 21 anak (40,39\%) masuk dalam kategori sedang dan 1 anak $(1,92 \%)$ masuk dalam kategori rendah.

Pada variabel minat terdapat 44 anak $(84,62 \%)$ yang memiliki minat kategori tinggi dan 8 anak $(15,38 \%)$ dalam kategori sedang. Variabel minat dalam penelitian ini diukur oleh empat indikator, yaitu perasaan, perhatian, ketertarikan dan keterlibatan. Secara rinci hasil penelitian terhadap indikator-indikator minat adalah sebagai berikut:

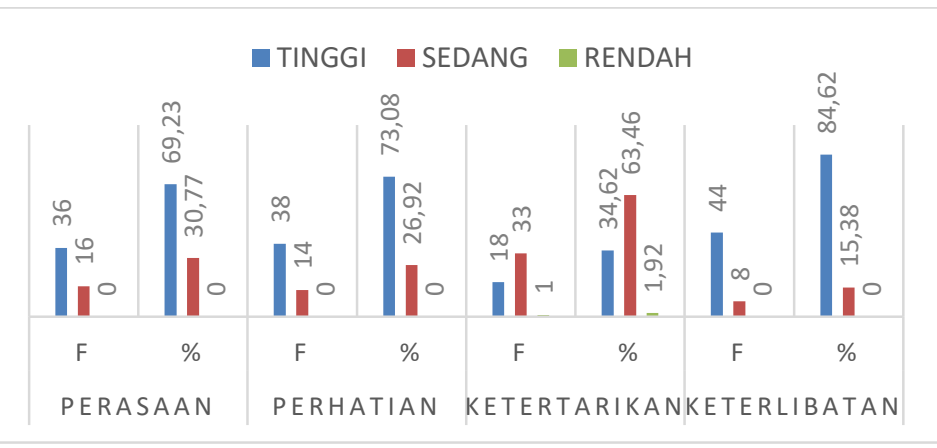

Gambar 3: Indikator Minat

Perasaan anak-anak dalam penelitian ini tergolong dalam kategori tinggi yaitu skor ratarata 21,04 dengan skor ideal 25. Terdapat 36 anak $(69,23 \%)$ memiliki perasaan dalam kategori tinggi, dan 16 anak (30,77\%) dalam kategori sedang. Sedangkan perhatian anakanak dalam penelitian ini tergolong kategori tinggi yaitu skor rata-rata 16, 67 dengan skor ideal 20. Terdapat 38 anak (73,08\%) memiliki perhatian yang tinggi dan 14 anak $(26,92 \%)$ memiliki perhatian yang sedang. Kemudian ketertarikan anak-anak dalam penelitian ini tergolong dalam kategori tinggi yaitu skor ratarata 4, 21 dengan skor ideal 5. Terdapat 18 anak $(34,62 \%)$ yang memiliki ketertarikan tinggi, 33 anak $(63,46 \%)$ dalam kategori sedang dan 1 anak $(1,92 \%)$ dalam kategori rendah.

Terakhir, keterlibatan anak-anak tergolong dalam kategori tinggi yaitu skor rata-rata 12,96 dengan skor ideal 15 . Terdapat 44 anak $(84,62 \%)$ yang memiliki keterlibatan tinggi dan 8 anak (15,38\%) tergolong dalam kategori sedang. 


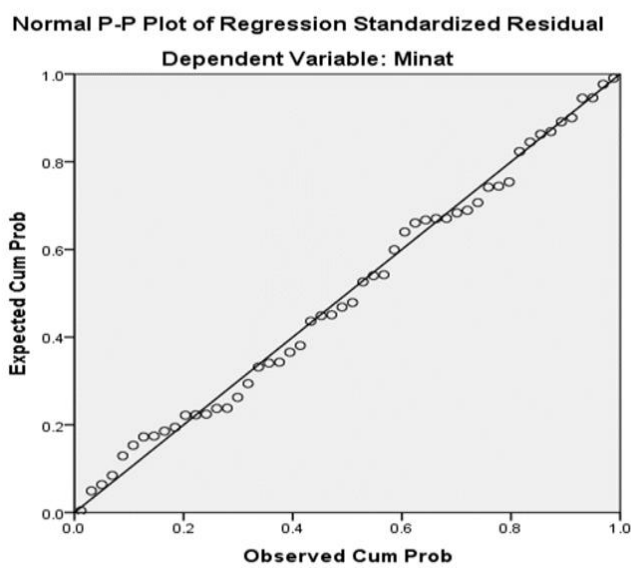

Gambar 4: Grafik Plot Hasil Uji Normalitas Data

Pada Tabel 2, terlihat hasil uji normalitas menggunakan Kolmogorov Smirnov dengan nilai signifikansi residual sebesar $0,200(\mathrm{p}>$ $0,05)$. Hal ini berarti data berdistribusi normal atau Ho diterima.

Tabel 2: Hasil Uji Normalitas

\begin{tabular}{llr}
\hline & & \multicolumn{2}{c}{$\begin{array}{c}\text { Unstandardized } \\
\text { Residual }\end{array}$} \\
\hline $\mathrm{N}$ & & 52 \\
\hline Normal Parameter & Mean Std & .0000000 \\
\hline & Deviation & 3.80815128 \\
\hline Most Extreme & Absoulute & .055 \\
\hline Differences & Positive & .055 \\
\hline \multicolumn{3}{c}{ Negative } \\
\hline Test Statistic & & -.052 \\
\hline Asymp. Sig. (2-tailed) & & .055 \\
\hline
\end{tabular}

Selanjutnya, hasil data berdistribusi normal juga dapat dibuktikan dalam uji normal $\mathrm{P}$ plot yang terdapat pada gambar 4, dimana titik-titik menyebar mendekati garis diagonal. Langkah kedua dalam melakukan analisis data adalah melakukan uji heteroskedastisitas. Pada penelitian ini, hasil uji heteroskedastisitas dapat dilihat pada gambar di bawah ini:

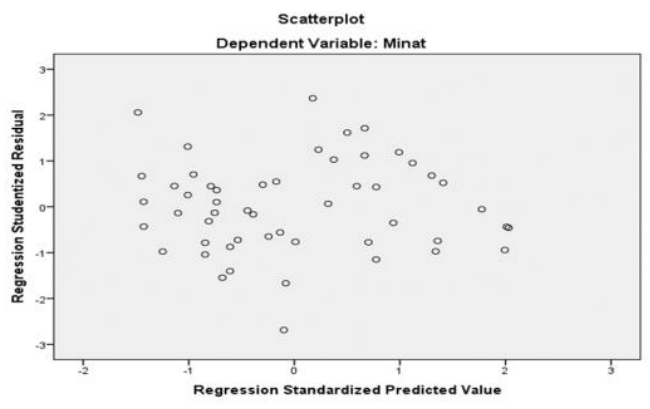

Gambar 5: Grafik Plot Hasil Uji Heteroskedastisitas

Melihat Gambar 5, uji heteroskedastisitas dapat terlihat pola titik-titik yang tidak beraturan dan titik-titik menyebar di atas dan di bawah angka o pada sumbu Y. Hal ini berarti varian dari seluruh variabel bebas yaitu pembelajaran asynchronous dan engagement learning dapat dikatakan signifikan. Langkah ketiga adalah dengan uji multikolinearitas. Apabila nilai tolerance $>0,10$ dan nilai VIF $<10$ maka dapat disimpulkan data tidak mengalami multikolinearitas

Diperoleh data bahwa pada pembelajaran asynchronous dan engagement learning samasama memiliki nilai tolerance $0,574(0,574>$ o,10) dan nilai VIF $1,741(1,741<10)$. Hal ini menunjukkan adanya korelasi yang tinggi pada variabel bebas dan tidak terjadi multikolinearitas. Data ini menggambarkan bahwa hubungan antar variabel bebas dengan variabel terikat dapat dianalisis pada langkah berikutnya.

Langkah keempat adalah ingin mengetahui adanya pengaruh pembelajaran asynchronous dan engagement learning secara simultan terhadap minat, maka dapat dilihat melalui hasil uji F pada tabel 11. Penjelasan dan penghitungannya adalah sebagai berikut: $\mathrm{F}$ tabel $=\mathrm{Fa} / 2\left(\mathrm{db}_{1}, \mathrm{db}_{2}\right) ; \mathrm{F} \mathrm{o,05/2}(1,52-2) ; \mathrm{F} \mathrm{O,025}$ (1, $50)=5.340323$. Berdasarkan tabel 7 , dapat dilihat bahwa nilai Fhitung sebesar 57.099 sedangkan nilai $F_{\text {tabel }}$ sebesar 5.340323. Jadi nilai $F$ hitung $\geq F$ tabel (57.099 $\geq 5.340323)$ dengan tingkat signifikansi $0.000<0,05$, sehingga $\mathrm{H}_{\mathrm{o}}$ ditolak dan $\mathrm{H}_{3}$ diterima. Kesimpulannya, pembelajaran asynchronous $\left(\mathrm{X}_{1}\right)$ dan engagement learning $\left(\mathrm{X}_{2}\right)$ adalah kedua 
variable memiliki pengaruh secara bersama secara sangat signifikan terhadap minat anakanak dalam mengikuti kegiatan sekolah minggu.

Selanjutnya melakukan uji regresi linear berganda guna mengetahui besarnya pengaruh variabel pembelajaran asynchronous $\left(\mathrm{X}_{1}\right)$ dan variabel engagement learning $\left(\mathrm{X}_{2}\right)$ terhadap variabel minat $(\mathrm{Y})$. Besarnya pengaruh yang terjadi dapat diketahui dengan melihat nilai $R$ Square:

Tabel 3: Hasil Uji Koefisien Determinasi

\begin{tabular}{c|c|c|c|c}
\hline Model & $\mathrm{R}$ & $\begin{array}{c}\mathrm{R} \\
\text { Square }\end{array}$ & $\begin{array}{c}\text { Adjusted } \\
\text { R Square }\end{array}$ & $\begin{array}{c}\text { Std. eror of } \\
\text { the } \\
\text { estimate }\end{array}$ \\
\hline 1 & $.837^{\mathrm{a}}$ & .700 & .687 & 3.885 \\
\hline
\end{tabular}

Berdasarkan tabel 3 diatas, diketahui bahwa hasil uji determinasi menunjukkan nilai $R$ Square 0.700. Hal ini berarti kontribusi variabel independen yaitu pembelajaran asynchronous $\left(\mathrm{X}_{1}\right)$ dan engagement learning $\left(\mathrm{X}_{2}\right)$ dalam menjelaskan variabel terikat yaitu minat anak-anak (Y) adalah sebesar 70\%. Sedangkan $30 \%$ sisanya dipengaruhi oleh faktor lain.

Persamaan regresi $\mathrm{Y}=7,975+0,212 \mathrm{X}_{1}+0,528$ $\mathrm{X}_{2}+\mathrm{e}$ melalui persamaan tersebut dapat disimpulkan bahwa: a) nilai constant sebesar 7,975 , b). nilai koefisien regresi media asynchronous learning sebesar 0,212 dan engagement learning sebesar 0,528 menunjukkan bahwa kedua nilai koefisien regresi memiliki nilai positif, maka dapat dikatakan bahwa penggunaan media asynchronous learning dan engagement learning yang tepat akan meningkatkan minat anak-anak dalam mengikuti kegiatan sekolah minggu.

\footnotetext{
23 Peter Draus, Michael Curran, and Melinda Trempus, "The Influence of Instructor-Generated Video Content on Student Satisfaction with and Engagement in Asynchronous Online Classes," Journal of Online Learning and Teaching 10, no. 2 (2014): 240.
}

\section{Diskusi}

Pada masa awal pandemi anak-anak mengikuti kegiatan Sekolah Minggu dari Youtube dan guru-guru Sekolah Minggu membagikan kepada anak-anak melalui whatsapp, media ini sebagai asynchronous learning. Penggunaan media Youtube ini dapat menjangkau anakanak Sekolah Minggu untuk belajar Firman Tuhan. Penggunaan video atau YouTube pada penelitian Draus dkk menunjukkan bahwa ada dampak positif pada penggunaan video pembelajaran pada kepuasan anak-anak, yang ditunjukkan melalui keterlibatan anak-anak dalam kegiatan pembelajaran. ${ }^{23}$

Hasil penelitian ini juga menunjukkan ada hubungan asynchronous learning pada minat anak-anak mengikuti kegiatan Sekolah Minggu. Strategi pembelajaran di Sekolah Minggu pada masa pandemi menjadi bagian yang penting, sesuai pendapat Zaluchu yang menyatakan bahwa instrumentasi dan integrasi menjadi jawaban atas kaum milenial pada sistem pendidikan generasi mileneal. Adanya penggunaan internet akan mengubah pola pikir anak-anak pada era digital ini. Budaya digital membutuhkan upaya untuk mengembangkan instrumen system pendidikan termasuk strategi pembelajaran, yang berangkat dari pola pikir digital. ${ }^{24}$ Sekolah Minggu juga perlu memiliki strategi pembelajaran untuk anak-anak Sekolah Minggu online ini.

Strategi pembelajaran yang digunakan perlu melibatkan anak-anak sehingga anak-anak memiliki minat mengikuti kegiatan, begitu juga di Sekolah Minggu. Salah satu indikator dari minat belajar adalah adanya keterlibatan anakanak dalam pembelajaran, dimana anak-anak menjadi pusat belajar (student center 
learning). ${ }^{25}$ Pada penelitian ini menunjukkan bahwa engaged learning yang dilakukan guruguru Sekolah Minggu melalui Youtube berdampak pada minat anak-anak dalam mengikuti kegiatan Sekolah Minggu. Hal ini sesuai dengan penelitian Sharma, bahwa pembelajaran yang melibatkan siswa ketika proses belajar sehingga siswa menjadi pusat pembelajaran (student center learning) maka akan meningkatkan minat siswa tersebut mengikuti pembelajaran. ${ }^{26}$

Adanya keterlibatan anak-anak pada pembelajaran di Sekolah Minggu akan membawa anak-anak generasi milenial ini tetap belajar Firman Tuhan walau Sekolah Minggu diadakan secara online, hal ini sesuai pendapat Yornan ${ }^{27}$ bahwa pada pendidikan Kristiani masih diperlukan sarana pembinaan spiritual yang Alkitabiah untuk generasi milenial ini. Hasil penelitian ini menunjukkan bahwa kegiatan anak-anak mengikuti Sekolah Minggu melalui Youtube (asynchronous learning) dan ajakan guru-guru Sekolah Minggu melalui Youtube (engagement learning) tersebut mempengaruhi minat anakanak Sekolah Minggu untuk mengikuti kegiatan yang diadakan oleh Sekolah Minggu. Data yang dianalisis dalam penelitian ini yang menunjukkan bahwa penggunaan media asynchronous learning dan engagement learning secara bersama-sama mampu memberikan dorongan atau minat pada anakanak untuk mengikuti kegiatan sekolah minggu, besarnya pengaruh antar variable terlihat dari angka r-square sebesar 70\% mempengaruhi minat anak-anak mengikuti kegiatan Sekolah Minggu. Hal ini sesuai dengan penelitian penggunaan media pada

\footnotetext{
25 Mariani Harmadi and Agung Jatmiko, "Pembelajaran Efektif Pendidikan Agama Kristen Generasi Milenial," PASCA : Jurnal Teologi Dan Pendidikan Agama Kristen 16, no. 1 (2020): 62-74, https://doi.org/10.46494/psc.v16i1.72.

${ }^{26}$ Deepak H. Sharma and Anjali Chachra, "Effective Learners' Engagement for Learning," Journal of Engineering Education Transformations 33, no. Special Issue (2020), https://doi.org/10.16920/jeet/2020/v33io/150084.
}

engagement learning berpengaruh terhadap ketertarikan anak-anak sehingga memiliki motivasi dalam mengikuti proses pembelajaran. ${ }^{28}$

\section{Kesimpulan}

Selama masa pandemi ini, penggunaan media YouTube sebagai asynchronous learning memiliki pengaruh pada minat anak-anak untuk mengikuti kegiatan Sekolah Minggu, anak-anak dapat melihat guru Sekolah Minggunya walaupun hanya di dunia maya. Selain itu, adanya strategi yang menarik di setiap tayangan YouTube akan membuat anakanak merasa terlibat dalam pembelajaran (engagement learning) di Sekolah Minggu sehingga anak-anak tetap memiliki minat mengikuti kegiatan Sekolah Minggu walau secara fisik, mereka tidak hadir di dalam gedung gereja.

\section{Referensi}

Choe, Ronny C., Zorica Scuric, Ethan Eshkol, Sean Cruser, Ava Arndt, Robert Cox, Shannon P. Toma, et al. "Student Satisfaction and Learning Outcomes in Asynchronous Online Lecture Videos." CBE Life Sciences Education 18, no. 4 (2019). https://doi.org/10.1187/cbe.18-o8-0171.

Chung, Ellen, Geetha Subramaniam, and Laura Christ Dass. "Online Learning Readiness among University Students in Malaysia amidst Covid-19." Asian Journal of University Education 16, no. 2 (2020): 45-58. https://doi.org/10.24191/AJUE.V16I2.10294.

Cohen, Louis, Lawrence Manion, and Keith Morrison. Research Methods in Education. Research Methods in Education. New York:

27 Yornan Masinambow and Yosef Nasrani, "Pendidikan Kristiani Sebagai Sarana Pembentukan Spiritualitas Generasi Milenial," PASCA: Jurnal Teologi Dan Pendidikan Agama Kristen 17, no. 1 (2021), https://doi.org/10.46494/psc.v17i1.114. ${ }^{28}$ Sesmiyanti Sesmiyanti, "Student's Cognitive Engagement in Learning Process," Journal Polingua : Scientific Journal of Linguistics, Literature and Education 5, no. 2 (2018), https://doi.org/10.30630/polingua.v5i2.34. 
Routledge, 2017.

https://doi.org/10.4324/9781315456539.

Douglas, Tracy, Allison James, Louise Earwaker, Carey Mather, and Sandra Murray. "Online Discussion Boards: Improving Practice and Student Engagement by Harnessing Facilitator Perceptions." Journal of University Teaching and Learning Practice 17, no. 3 (2020).

https://doi.org/10.53761/1.17.3.7.

Draus, Peter, Michael Curran, and Melinda Trempus. "The Influence of InstructorGenerated Video Content on Student Satisfaction with and Engagement in Asynchronous Online Classes." Journal of Online Learning and Teaching 10, no. 2 (2014): 240.

Dziuban, Charles, Patsy Moskal, Jay Brophy, and Peter Shea. "STUDENT SATISFACTION WITH ASYNCHRONOUS LEARNING." Online Learning 11, no. 1 (2019). https://doi.org/10.24059/olj.v11i1.1739.

Garber, Adam M. "Flipping Out! Utilizing an Online Micro-Lecture for Asynchronous Learning Within the Acting Internship." Medical Science Educator 30, no. 1 (2020). https://doi.org/10.1007/s40670-019-00887y.

Geraniou, Eirini, and Cosette Crisan. "University Students' Engagement with an Asynchronous Online Course on Digital Technologies for Mathematical Learning." Eleventh Congress of the European Society for Research in Mathematics Education, no. 2002 (2019).

Gómez-Rey, Pilar, Elena Barbera, and Francisco Fernández-Navarro. "Student Voices on the Roles of Instructors in Asynchronous Learning Environments in the 21st Century." International Review of Research in Open and Distance Learning 18, no. 2 (2017). https://doi.org/10.19173/irrodl.v18i2.2891.

Harmadi, Mariani, and Agung Jatmiko.

"Pembelajaran Efektif Pendidikan Agama Kristen Generasi Milenial.” PASCA : Jurnal Teologi Dan Pendidikan Agama Kristen 16, no. 1 (2020): 62-74. https://doi.org/10.46494/psc.v16i1.72.

Javed, Muhammad, Akhtar Ali, and Azhar Mahmood. "Impact of Globalization on Postgraduate Students' Asynchronous Learning in English Language." Pakistan Journal of Distance and Online Learning 4, no. 2 (2018): 67-86.
Karnawati, Karnawati, and Mardiharto Mardiharto. "Sekolah Minggu Masa Pandemi Covid 19: Kendala, Solusi, Proyeksi." Didache: Journal of Christian Education 1, no. 1 (2020): 13. https://doi.org/10.46445/djce.v1i1.291.

Lew, Edward K., and Erik K. Nordquist. "Asynchronous Learning: Student Utilization out of Sync with Their Preference." Medical Education Online 21, no. 1 (2016). https://doi.org/10.3402/meo.v21.30587.

Masinambow, Yornan, and Yosef Nasrani. "Pendidikan Kristiani Sebagai Sarana Pembentukan Spiritualitas Generasi Milenial.” PASCA: Jurnal Teologi Dan Pendidikan Agama Kristen 17, no. 1 (2021). https://doi.org/10.46494/psc.v17i1.114.

Mukhtar, Khadijah, Kainat Javed, Mahwish Arooj, and Ahsan Sethi. "Advantages, Limitations and Recommendations for Online Learning during Covid-19 Pandemic Era.” Pakistan Journal of Medical Sciences 36, no. COVID19$\mathrm{S} 4$ (2020). https://doi.org/10.12669/pjms.36.COVID19S4.2785.

Northey, Gavin, Tania Bucic, Mathew Chylinski, and Rahul Govind. "Increasing Student Engagement Using Asynchronous Learning." Journal of Marketing Education 37, no. 3 (2015). https://doi.org/10.1177/0273475315589814.

Reeve, Johnmarshall, and Ching Mei Tseng. "Agency as a Fourth Aspect of Students' Engagement during Learning Activities." Contemporary Educational Psychology 36, no. 4 (2011). https://doi.org/10.1016/j.cedpsych.2011.05.0 02.

Saadiah, Halimatus, and Abdul Wahid. "Are Students Engaging in Online Classrooms?” European Journal of Education Studies 7, no. 2019 (2020): 202-22. https://doi.org/10.46827/ejes.v7i12.3408.

Sesmiyanti, Sesmiyanti. "Student's Cognitive Engagement in Learning Process." Journal Polingua : Scientific Journal of Linguistics, Literature and Education 5, no. 2 (2018). https://doi.org/10.30630/polingua.v5i2.34.

Sharma, Deepak H., and Anjali Chachra. "Effective Learners' Engagement for Learning." Journal of Engineering Education Transformations 33 , no. Special Issue (2020). https://doi.org/10.16920/jeet/2020/v33io/15 o084. 
Sholehah, Siti Hidayatus, Diana Endah Handayani, and Singgih Adhi Prasetyo. "Minat Belajar Siswa Pada Mata Pelajaran Matematika Kelas IV SD Negeri Karangroto 04 Semarang." Mimbar Ilmu 23, no. 3 (2018). https://doi.org/10.23887/mi.v23i3.16494.

Sistek-Chandler Ed., Cynthia Mary. Exploring Online Learning through Synchronous and Asynchronous Instructional Methods. Advances in Mobile and Distance Learning (AMDL) Book Series. IGI Global, 2020. https://doi.org/http://dx.doi.org/10.4018/97 8-1-7998-1622-5.

Teng, Michael, and Carmia Margaret. "Sketsa Pelayanan Gereja Sebelum, Selama, Dan Sesudah Masa Pandemi COVID-19." Veritas: Jurnal Teologi Dan Pelayanan, 2020. https://doi.org/10.36421/veritas.v19i2.432.

Yunitasari, Ria, and Umi Hanifah. "Pengaruh Pembelajaran Daring Terhadap Minat Belajar Siswa Pada Masa COVID 19." EDUKATIF : JURNAL ILMU PENDIDIKAN 2, no. 3 (2020). https://doi.org/10.31004/edukatif.v2i3.142.

Yusup Rogo Yuono. "Pertumbuhan Gereja Di Masa Pandemi." Sagacity 65, no. 2 (2020).

Zaluchu, Sonny. "The Digital Mindset as an Approach to Education Forthe Millenial Generation.” In ICOGESS, edited by Suardin Gaurifa. Medan: EAI, 2020.

https://doi.org/10.4108/eai.14-32019.2292036.

Zaluchu, Sonny Eli. Sistematika Riset Dan Analisis Data Kuantitatif. Semarang: Golden Gate Publishing, 2018.

Zhang, Xiaoyu, Xiaofeng Chen, Joseph K. Liu, and Yang Xiang. "DeepPAR and DeepDPA:

Privacy Preserving and Asynchronous Deep Learning for Industrial IoT.” IEEE Transactions on Industrial Informatics 16, no. 3 (2020).

https://doi.org/10.1109/TII.2019.2941244. 